\title{
Kinetics of Thermolysis of Nickel(II) Perchlorate Complex with n-Propylamine
}

\author{
Chandra Prakash Singh and Abhishek Singh \\ Department of Chemistry, DBS College, Kanpur 208006, India \\ Correspondence should be addressed to Chandra Prakash Singh; cpsingh4us@gmail.com
}

Received 25 November 2013; Accepted 10 January 2014; Published 19 February 2014

Academic Editors: J. Luo and H. S. Yathirajan

Copyright ( 2014 C. P. Singh and A. Singh. This is an open access article distributed under the Creative Commons Attribution License, which permits unrestricted use, distribution, and reproduction in any medium, provided the original work is properly cited.

Complex of nickel perchlorate with n-propylamine has been synthesised with molecular formula $\left[\mathrm{Ni}(\mathrm{n}-\mathrm{pa})_{3}\left(\mathrm{ClO}_{4}\right)\left(\mathrm{H}_{2} \mathrm{O}\right)\right] \mathrm{ClO}$. It has been characterised by elemental analysis, thermogravimetry, UV-VIS, and IR spectroscopic data. Thermal properties have been investigated by thermogravimetry (TG) in static air and by simultaneous thermogravimetry-derivative thermogravimetrydifferential thermal analysis (TG-DTG-DTA) in flowing nitrogen atmosphere. Kinetics of thermolysis has been analysed applying model-fitting and model-free isoconversional method on isothermal TG data recorded at five different temperatures. To observe the response of complex towards fast heating, explosion delay time has been recorded at various temperatures and kinetics of explosion has been studied using these data.

\section{Introduction}

Metal perchlorates have strong oxidizing properties and amines are reducing in nature. Amines have strong $\mathrm{e}^{-}$ donation power due to presence of lone pair $\mathrm{e}^{-}$on their nitrogen atom. These two oxidizing and reducing groups can be easily incorporated in a single molecule by reacting metal perchlorate with amine resulting in the formation of metal amine perchlorate coordination compounds. Any composition having strong oxidizing and reducing groups simultaneously in a molecule will exhibit the properties of high energetic materials. Thus, metal perchlorate amine complexes will exhibit the properties of energetic material and undergo autotransmitted decomposition reactions [1-3] when subjected to a stimuli (heat, friction, shock, wave, etc.). Owing to their energetic properties these types of complexes have found applications in explosives, pyrotechnics, and propellants. Such type of complexes has been proved to be a strong burning rate modifier for hydroxyl terminated polybutadiene-ammonium perchlorate (HTPB-AP) based propellants $[4,5]$. In search of insensitive high energetic materials, a strong interest is being given by the researches on such type of complexes (having oxidizing and reducing group in one molecule) and they have been synthesized and their properties have been extensively investigated [5-14]. In the present paper, we report the preparation, characterisation, thermolysis, and explosion characterisation of nickel perchlorate complex with n-propyl amine, water, and $\mathrm{ClO}_{4}{ }^{-}$ as ligands. Kinetics of early thermolysis was also investigated by applying model-fitting and isoconversional method.

\section{Experimental}

2.1. Materials. Nickel carbonate, perchloric acid, n-propyl amine (sd.fine), ethanol (Changshu Yangyuan Chemical, China), petroleum ether (Merk), and all of AR grades were used as received.

2.2. Preparation. The complex was prepared via two-step procedure. In first step hexahydrate nickel perchlorate was obtained by reacting nickel carbonate with $60 \%$ perchloric acid followed by recrystallisation. In second step, ethanolic solution of nickel perchlorate and n-propyl amine was mixed together, stirred well at room temperature, and filtered out some obtained light green ppt. From the filtrate, after 2-3 days 
TABLE 1: IR frequencies and elemental analysis data for the complex.

\begin{tabular}{lccc}
\hline$\nu\left(\mathrm{cm}^{-1}\right)$ & IR Assignments & \multicolumn{2}{c}{ Element \%, observed/calculated } \\
\hline 448 & M-N & $\mathrm{C}$ & $22.4 / 22.1$ \\
627 & Ionic perchlorate & $\mathrm{N}$ & $8.6 / 8.5$ \\
753 & $\mathrm{C}-\mathrm{H}$ def & $\mathrm{H}$ & $6.1 / 6.4$ \\
990 & $\mathrm{C}-\mathrm{N}$ str. & $\mathrm{Ni}$ & $12.95 / 13.27$ \\
1089 & Ionic perchlorate & & \\
1112 & Bidentate & & \\
1145 & $\mathrm{ClO}_{4}^{-}$ & & \\
1395 & $\mathrm{C}^{-} \mathrm{NH}_{2}$ & & \\
1503 & $\mathrm{~N}-\mathrm{H}$ bend. & \\
1570 & & \\
2705 & $\mathrm{C}-\mathrm{H}$ str. & \\
2994 & $\mathrm{NH}$ (Pri) & \\
3034 & $\mathrm{O}-\mathrm{H}\left(\mathrm{H}_{2} \mathrm{O}\right)$ & \\
3434 &
\end{tabular}

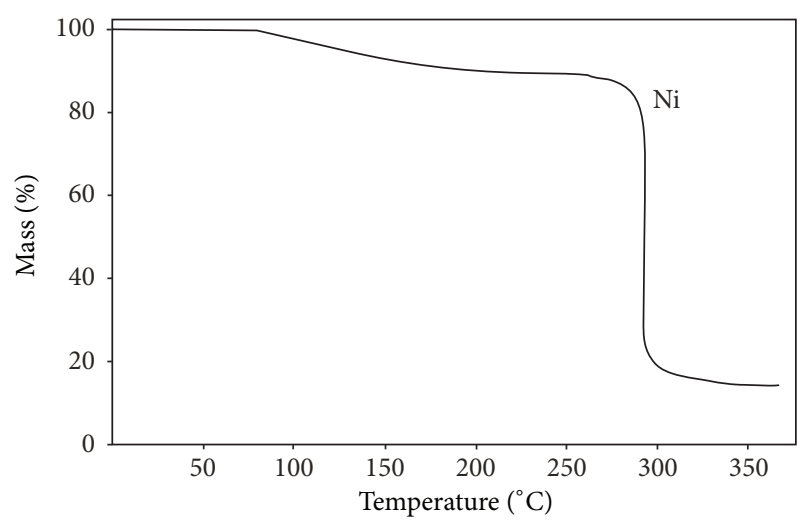

FIGURE 1: TG curve of complex in static air atmosphere.

light green crystals of desired complex were obtained. The crystals were washed with alcohol and dried.

Caution. Perchlorates are explosives. They should be handled with care. However, I have not found any problem during all experimental procedures.

2.3. Characterisation. Characterisation of complex was done by elemental analysis (C, H, N; Thermo Finnigan Flash EA 1112 CHNS analyzer), infrared [15-17] (Perkin Elmer FT-IR spectrometer), UV-VIS spectroscopy and thermogravimetry (Table 1).

\subsection{Thermal Analysis}

2.4.1. TG in Air. Thermogravimetry in static air with heating rate of $10^{\circ} \mathrm{C} / \mathrm{min}$ (Figure 1) was recorded using an indigenously fabricated TG apparatus [18] (sample mass $20 \mathrm{mg}$ ).

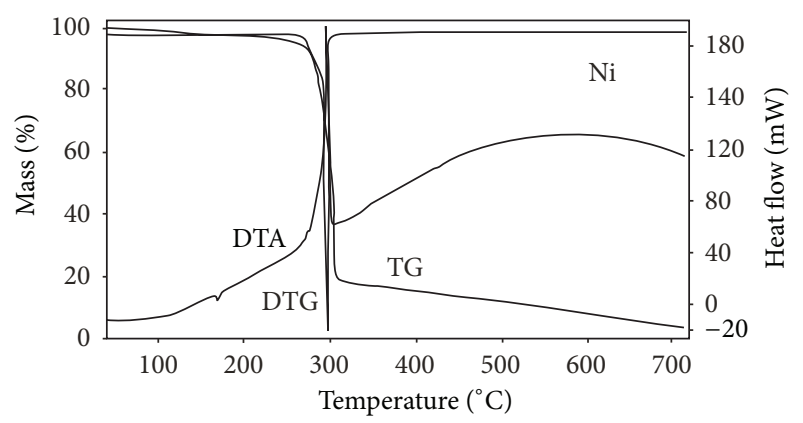

Figure 2: TG-DTG-DTA curve of complex in flowing nitrogen atmosphere.

2.4.2. Simultaneous TG-DTG-DTA. These traces were obtained in flowing nitrogen atmosphere $(100 \mathrm{~mL} / \mathrm{min})$, sample was $\sim 2.5 \mathrm{mg}$ at a heating rate of $10^{\circ} \mathrm{C} / \mathrm{min}$ (Figure 2, Table 2).

2.4.3. Isothermal TG. Isothermal TG (Figure 3) was recorded in static air atmosphere using the same indigenously fabricated TG apparatus as mentioned earlier at five different temperatures $\left(200,210,220,230\right.$, and $\left.240^{\circ} \mathrm{C}\right)$. Sample mass taken was $10 \mathrm{mg}$ and readings were recorded for $30 \%$ decomposition.

2.4.4. Kinetic Analysis. Kinetics of decomposition has been investigated using isothermal TG data using model fitting (Table 3) [19] and isoconversional method [20, 21]. Variation of activation energy with extent of conversion $\alpha$ is shown in Figure 4.

2.4.5. Explosion Delay Experiments. This experiment was performed using tube furnace technique [22] (sample mass $10 \mathrm{mg}$ ) at temperatures of $280,300,320,340$, and $360^{\circ} \mathrm{C}$ within experimental limit of $\pm 1^{\circ} \mathrm{C}$ (Table 4). $D_{E}$ data were fitted in Arrhenius equation

$$
D_{E}=A \exp \frac{E^{*}}{R T}
$$

where $A$ is the Arrhenius factor, $E^{*}$ is the activation energy for explosion, $T$ is absolute temperature, and $R$ is the gas constant. A plot of $\ln D_{E}$ versus $1 / T$ is presented in Figure 5.

\section{Results and Discussion}

Table 1 containing elemental analysis and IR data shows a good agreement between observed and calculated percentages of $\mathrm{C}, \mathrm{H}, \mathrm{N}$, and $\mathrm{Ni}$. The FT-IR spectra of the complex revealed bands at $448 \mathrm{~cm}^{-1}$ assigned to $v(\mathrm{M}-\mathrm{N})$, 627 and $1089 \mathrm{~cm}^{-1}$ assigned to ionic perchlorate, and 1112 and $1145 \mathrm{~cm}^{-1}$ assigned to bidentate perchlorate ion $\left(\mathrm{C}_{2 \mathrm{~V}}\right.$ symmetry) [22]. A broad peak at $3434 \mathrm{~cm}^{-1}$ is due to $v(\mathrm{O}-\mathrm{H})$ of coordinated water. Other peaks are according to standard text. In the UV-VIS spectrum, the absorption maxima at $263 \mathrm{~nm}$ is due to $\mathrm{n} \rightarrow \pi^{*}$ transition and a peak at $378 \mathrm{~nm}$ is assigned for ${ }^{3} \mathrm{~A}_{2 \mathrm{~g}}(\mathrm{~F}) \rightarrow{ }^{3} \mathrm{~T}_{1 \mathrm{~g}}(\mathrm{P})$ overlapping with charge 
TABLE 2: TG-DTA data of the complex.

\begin{tabular}{lccccc}
\hline Step & & TG & & DTA & \\
& Temperature range $\left({ }^{\circ} \mathrm{C}\right)$ & \% decomposition & Peak position $\left({ }^{\circ} \mathrm{C}\right)$ & Nature of peaks \\
\hline I & $92-121$ & 4 & 169 & Endo \\
II & $121-288$ & 12 & - & - \\
III & $290-305$ & 70 & 299 & Exo \\
\hline
\end{tabular}

Table 3: Activation energy (E), Arrhenius factor, and correlation coefficients $(r)$ for the isothermal decomposition of the complex.

\begin{tabular}{|c|c|c|c|c|c|c|c|}
\hline Serial number & Model & $\ln A$ & Slope & $E / \mathrm{kJ} \mathrm{mole}^{-1}$ & $r$ & Mean deviation & Standard deviation \\
\hline 1 & Power law ${ }^{3 / 4}$ & 1.1382 & 2128.2 & 17.7 & 0.9702 & 2.728 & 2.877 \\
\hline 2 & Power law ${ }^{2 / 3}$ & 1.2143 & 1978.1 & 16.4 & 0.9641 & 2.613 & 2.756 \\
\hline 3 & Power law ${ }^{1 / 2}$ & 0.6130 & 2148.7 & 17.8 & 0.9714 & 2.486 & 2.628 \\
\hline 4 & Power law ${ }^{-1 / 2}$ & 0.0605 & 2207.1 & 18.3 & 0.9740 & 2.269 & 2.384 \\
\hline 5 & Power law ${ }^{-1}$ & -0.0051 & 2224.6 & 18.5 & 0.9742 & 2.254 & 2.378 \\
\hline 6 & Mampel $(1-\alpha)$ & -1.1053 & 2275.1 & 18.9 & 0.9610 & 1.755 & 1.853 \\
\hline 7 & $a-e^{3 / 4}$ & 0.7241 & 2177.1 & 18.1 & 0.9748 & 2.570 & 2.711 \\
\hline 8 & $a-e^{2 / 3}$ & -0.0275 & 2249.8 & 18.7 & 0.9599 & 2.268 & 2.390 \\
\hline 9 & $a-e^{1 / 2}$ & -0.4144 & 2260.2 & 18.8 & 0.9605 & 2.085 & 2.201 \\
\hline 10 & cs & 0.2240 & 2249.1 & 18.7 & 0.9686 & 2.393 & 2.525 \\
\hline 11 & T-d-diff & 0.2629 & 2305.1 & 19.1 & 0.9614 & 2.470 & 2.605 \\
\hline 12 & $\mathrm{cc}$ & 0.1869 & 2223.4 & 18.5 & 0.9713 & 2.349 & 2.478 \\
\hline 13 & P-T & -1.6300 & 2237.5 & 18.6 & 0.9592 & 1.454 & 1.536 \\
\hline 14 & G-B & 1.2040 & 2256.1 & 18.7 & 0.9698 & 2.891 & 3.049 \\
\hline
\end{tabular}

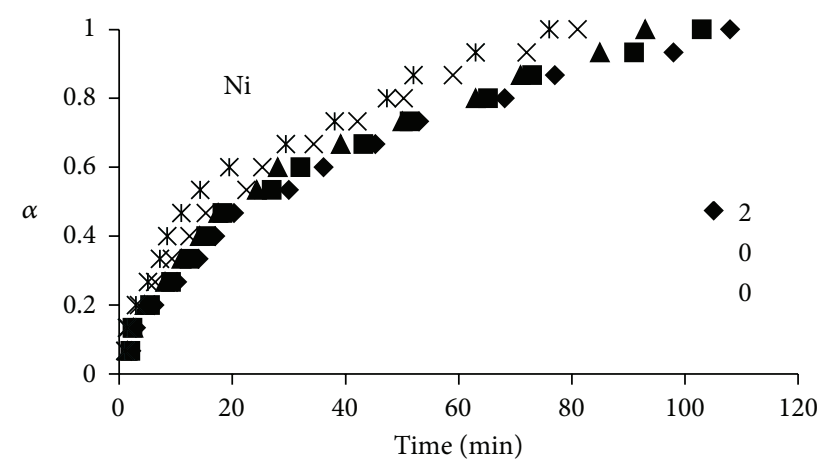

FIGURE 3: Isothermal TG of complex in static air atmosphere at different temperatures.

transfer band. A band at $870 \mathrm{~nm}$ is assigned for ${ }^{3} \mathrm{~A}_{2 \mathrm{~g}}(\mathrm{~F}) \rightarrow$ ${ }^{1} \mathrm{E}_{\mathrm{g}}(\mathrm{D})$ transition. Thus, as suggested by the overall evidence given above, the complex can be formulated as $[\mathrm{Ni}(\mathrm{n}-$ pa $\left.)_{3}\left(\mathrm{ClO}_{4}\right)\left(\mathrm{H}_{2} \mathrm{O}\right)\right] \mathrm{ClO}_{4}$ in which $\mathrm{Ni}^{2+}$ is hexacoordinated. Out of six coordination sites, three sites are satisfied with nitrogen atoms; one from each n-propylamine and three sites with O-atoms; one from water molecule and two from one of the perchlorate ions acting as a bidentate ligand $\left(\mathrm{C}_{2 \mathrm{~V}}\right.$ symmetry).

A perusal of TG curve recorded in static air with linear temperature increase shows that the complex decomposes in three steps. The very first step $\left(92-121^{\circ} \mathrm{C}\right)$ is gradual in which

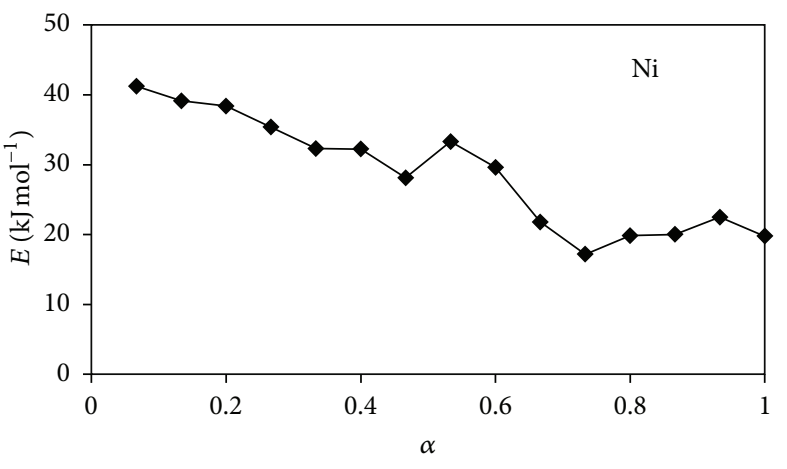

FIgURE 4: Variation of activation energy of thermolysis for the complex with extent of conversion $(\alpha)$.

coordinated $\mathrm{H}_{2} \mathrm{O}$ leaves the complex ( $\sim 4 \mathrm{wt}$. Loss). In the second step $\left(121-288^{\circ} \mathrm{C}\right)$ one of the n-propylamines is released ( $\sim 12 \%$ wt. Loss). In the third step $\left(290-305^{\circ} \mathrm{C}\right)$ the remaining residue $\left[\mathrm{Ni}(\mathrm{n} \text {-pa })_{2}\left(\mathrm{ClO}_{4}\right)\right] \mathrm{ClO}_{4}$ (might be tetracoordinated complex of $\mathrm{Ni}^{2+}$ ) ignites with smoke and low noise giving a sharp weight loss $(\sim 70 \%)$. At lost $\sim 15 \%$ mass is left which corresponds to $\mathrm{NiO}$ (calculated mass $15.27 \%$ ). In flowing $\mathrm{N}_{2}$ atmosphere (Figure 2) the decomposition pattern of complex is similar to static air. A DTG peak has been obtained corresponding to third step sudden weight loss. DTG were not obtained for first step because this step is very gradual. DTG peak for second step might be incorporated in third step 
TABLE 4: Explosion delay, activation energy for thermal explosion $\left(E^{*}\right)$, and correlation coefficient $(r)$ of complex.

\begin{tabular}{lccccccr}
\hline \multicolumn{5}{c}{$D_{E} D_{E}(\mathrm{~s})$ at temperature $\left({ }^{\circ} \mathrm{C}\right)$} & & $E^{*}\left(\mathrm{~kJ} \mathrm{~mol}^{-1}\right)$ & $r$ \\
$280 \pm 1$ & $300 \pm 1$ & $320 \pm 1$ & $340 \pm 1$ & $360 \pm 1$ & & \\
\hline 123 & 93 & 83 & 58 & 54 & 30.9 & 0.9842 \\
\hline
\end{tabular}

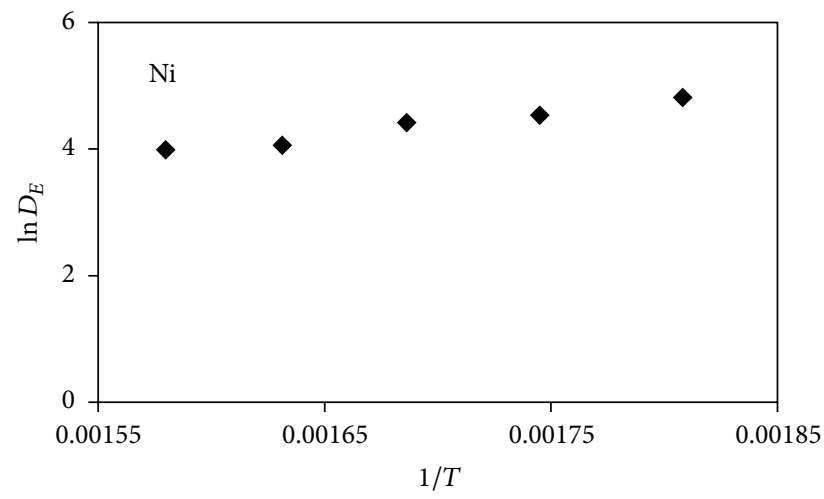

FIGURE 5: Graph representing $\ln D_{E}$ versus $1 / T$ for the complex.

of DTG peak. In DTA curve an endotherm at $169^{\circ} \mathrm{C}$ and this is to be in harmony with second step (removal of one of the npa molecule). A strong exothermic peak at $299^{\circ} \mathrm{C}$ has been received which suits the ignition of partially decomposed residue in the third step.

Thus, in the light of the above discussion, the thermolysis pattern of the complex can be given as

$$
\begin{aligned}
& {\left[\mathrm{Ni}(\mathrm{n}-\mathrm{pa})_{3}\left(\mathrm{ClO}_{4}\right)\left(\mathrm{H}_{2} \mathrm{O}\right)\right] \mathrm{ClO}_{4}} \\
& \quad \stackrel{-\mathrm{H}_{2} \mathrm{O}}{\mathrm{92-121^{ \circ } \mathrm { C }}}\left[\mathrm{Ni}(\mathrm{n}-\mathrm{pa})_{3}\left(\mathrm{ClO}_{4}\right)\right] \mathrm{ClO}_{4} \\
& {\left[\mathrm{Ni}(\mathrm{n}-\mathrm{pa})_{3}\left(\mathrm{ClO}_{4}\right)\right] \mathrm{ClO}_{4}} \\
& \quad \stackrel{-\mathrm{n}-\mathrm{pa}}{121-288^{\circ} \mathrm{C}}\left[\mathrm{Ni}(\mathrm{n}-\mathrm{pa})_{2}\left(\mathrm{ClO}_{4}\right)\right] \mathrm{ClO}_{4} \\
& {\left[\mathrm{Ni}(\mathrm{n}-\mathrm{pa})_{2}\left(\mathrm{ClO}_{4}\right)\right] \mathrm{ClO}_{4}} \\
& \stackrel{290-305^{\circ} \mathrm{C}}{\longrightarrow} \mathrm{NiO}+\text { gaseous products }
\end{aligned}
$$

In the order to calculate activation energy $\left(E_{a}\right)$ for the removal of ligands (30\% wt. Loss which includes $\mathrm{H}_{2} \mathrm{O}$ and 2 n-pa molecule), a set of reaction models (Table 3) [19] was used on isothermal TG data in the temperature range $200-240^{\circ} \mathrm{C}$ (Figure 3$) . E_{a}$ values obtained $\left(\sim 18 \mathrm{~kJ} \mathrm{~mole}{ }^{-1}\right)$ are almost equal irrespective of the reaction model used.

Kinetic analysis of isothermal TG data applying isoconversional method $[20,21]$ concerns with the calculation of activation energy independent of the model but corresponding to the extent of conversion $(\alpha)$ of the complex. Figure 4 shows that at different values of $\alpha, E_{a}$ values in are different. Model-free isoconversional method is a better approach to obtain reliable and consistent kinetic data as compared to model-fitting methods.
The complex when subjected to sudden high temperature explodes with noise. To determine the activation energy of explosion $\left(E^{*}\right)$ explosion delay time has been recorded at five different temperatures (Table 4). Activation energy for explosion was found to be $30.9 \mathrm{~kJ} \mathrm{~mol}^{-1}$. A graph of $\ln D_{E}$ versus $1 / T$ (Figure 5) shows that explosion delay time exponentially depends on temperatures.

\section{Conclusion}

The complex has been prepared and characterised by various techniques. TG-DTA study reveals that the complex decompose in three steps. After an initial weight loss ( 16\%) oxidiser $\left(\mathrm{ClO}_{4}{ }^{-}\right)$and fuel (reducing group i.e., n-pa) lead to ignition giving a sharp exothermic peak in DTA. End product of thermolysis corresponds to $\mathrm{NiO}$. Complex explodes when kept suddenly under high temperatures.

\section{Conflict of Interests}

The authors declare that there is no conflict of interests regarding the publication of this paper.

\section{Acknowledgments}

The authors thank the Secretary Board of Management, Principal and Head of Department of Chemistry, DBS College, Kanpur, for providing laboratory facilities, and University Grants Commission, New Delhi, for financial assistance. Thanks are also due to Sophisticated Test and Instrumentation Centre, Cochin University of Science and Technology, for CHN, FT-IR, UV-VIS, and TG-DTA analyses.

\section{References}

[1] G. Singh, C. P. Singh, and S. M. Mannan, "Kinetics of thermolysis of some transition metal perchlorate complexes with 1,4diaminobutane ligand," Thermochimica Acta, vol. 437, no. 1-2, pp. 21-25, 2005.

[2] G. Singh and D. K. Pandey, "Studies on energetic compounds: part 40. Kinetics of thermal decomposition of some bis(propylenediamine)metal perchlorate complexes," Journal of Thermal Analysis and Calorimetry, vol. 82, no. 2, pp. 353-360, 2005.

[3] G. Singh, S. P. Felix, and D. K. Pandey, "Studies on energetic compounds part 37: kinetics of thermal decomposition of perchlorate complexes of some transition metals with ethylenediamine," Thermochimica Acta, vol. 411, no. 1, pp. 61-71, 2004.

[4] G. Singh, I. P. S. Kapoor, and D. K. Pandey, "Hexammine metal perchlorates as energetic burning rate modifiers," Journal of Energetic Materials, vol. 20, pp. 223-244, 2002. 
[5] G. Singh and D. K. Pandey, "Studies on energetic compounds part 27: kinetics and mechanism of thermolysis of bis(ethylenediamine) metal nitrate and their role in the burning rate of solid propellants," Propellants, Explosives, Pyrotechnics, vol. 28, no. 5, pp. 231-239, 2003.

[6] K. C. Patil, V. R. P. Verneker, and S. R. Jain, "Role of metal perchlorate ammines on ammonium perchlorate decomposition," Combustion and Flame, vol. 25, pp. 387-388, 1975.

[7] K. S. Rejitha and S. Mathew, "Thermal behaviour of nickel(II) sulphate, nitrate and halide complexes containing ammine and ethylenediamine as ligands: kinetics and evolved gas analysis," Journal of Thermal Analysis and Calorimetry, vol. 106, no. 1, pp. 267-275, 2011.

[8] F. Walmsley, A. A. Pinkerton, and J. A. Walmsley, "Synthesis and x-ray crystal structures of 1:1 complexes of nickel(II) nitrate with 1,10-phenanthroline and with 2,2' -bipyridyl," Polyhedron, vol. 8, no. 5, pp. 689-693, 1989.

[9] L. Jianmin, Z. Jianbin, K. Yanxiong, and W. Xintao, "A novel structure of bipyridine coordinated with copper (II): [Cu(bipy) $\left.\left(\mathrm{H}_{2} \mathrm{O}\right)_{3}\right]\left(\mathrm{NO}_{3}\right)_{2}$," Crystal Research and Technology, vol. 31, no. 5, pp. 589-593, 1996.

[10] A. Rujiwatra, S. Yimklan, and T. J. Prior, "A second crystal form of $\left[\mathrm{Ni}\left(2,2^{\prime}\right.\right.$-bipyridine $\left.)\left(\mathrm{H}_{2} \mathrm{O}\right)_{3}\left(\mathrm{NO}_{3}\right)\right]\left(\mathrm{NO}_{3}\right)$ featuring a different molecular orientation," Polyhedron, vol. 31, no. 1, pp. 345-351, 2012.

[11] D. Kumar, I. P. S. Kapoor, G. Singh, N. Goel, and U. P. Singh, "Preparation, characterization and thermal behaviour of polymeric complex of cadmium hexamethylenetetramine nitrate," Solid State Sciences, vol. 14, no. 4, pp. 495-500, 2012.

[12] G. Singh, I. P. S. Kapoor, D. Kumar, U. P. Singh, and N. Goel, "Preparation, X-ray crystallography and thermal decomposition of transition metal perchlorate complexes with perchlorate and 2,2' -bipyridyl ligands," Inorganica Chimica Acta, vol. 362, no. 11, pp. 4091-4098, 2009.

[13] K. Dinesh, I. P. S. Kapoor, G. Singh, and R. Frohlich, "Preparation, characterization and kinetics of thermolysis of nickel and copper nitrate complexes with $2,2^{\prime}$-bipyridine ligands," Thermochimica Acta, vol. 545, pp. 67-74, 2012.

[14] D. Kumar, I. P. S. Kapoor, G. Singh, N. Goel, and U. P. Singh, "Preparation, X-ray crystallography and thermolysis of transition metal nitrates of 2,2' - bipyridine (Part 63)," Journal of Thermal Analysis and Calorimetry, vol. 107, no. 1, pp. 325-334, 2012.

[15] K. Nakamoto, Infrared and Raman Spectra of Inorganic and CoOrdination Compounds, Wiley, New York, NY, USA, 1978.

[16] C. W. Robert, Handbook of Physics and Chemistry, vol. 66, CRC Press, Boca Raton, Fla, USA, 1996.

[17] F. A. Miller and C. H. Wilkins, "Infrared spectra and characteristic frequencies of inorganic ions: their use in qualitative analysis," Analytical Chemistry, vol. 24, no. 8, pp. 1253-1294, 1952.

[18] G. Singh and R. R. Singh, "Indigenously fabricated apparatus for thermogravimetric analysis," Research Industry, vol. 23, pp. 92-103, 1978.

[19] M. E. Brown, D. Dollimore, and A. K. Galway, Reactions in the Solid State, Comprehensive Chemical Kinetics, vol. 22, Elsevier, Amsterdam, The Netherlands, 1997.

[20] S. Vyazovkin and C. A. Wight, "Isothermal and nonisothermal reaction kinetics in solids: in search of ways toward consensus,"
Journal of Physical Chemistry A, vol. 101, no. 44, pp. 8279-8284, 1997.

[21] S. Vyazovkin and C. A. Wight, "Model-free and model-fitting approaches to kinetic analysis of isothermal and nonisothermal data," Thermochimica Acta, vol. 340-341, pp. 53-68, 1999.

[22] G. Singh, I. P. S. Kapoor, and S. K. Vasudeva, "Thermolysis of AP-PS additive mixtures," Indian Journal of Technology, vol. 29, pp. 589-594, 2004. 

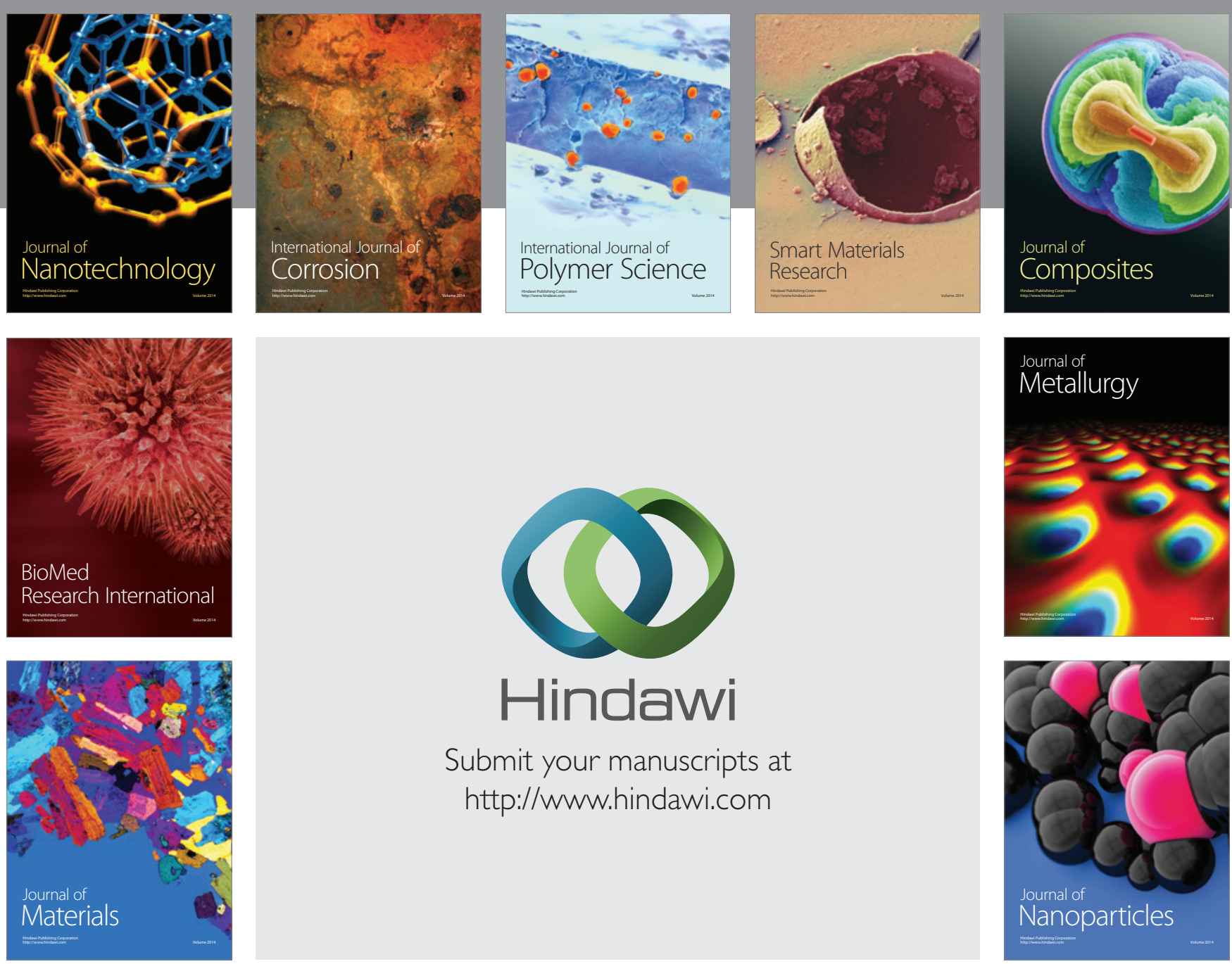

Submit your manuscripts at http://www.hindawi.com
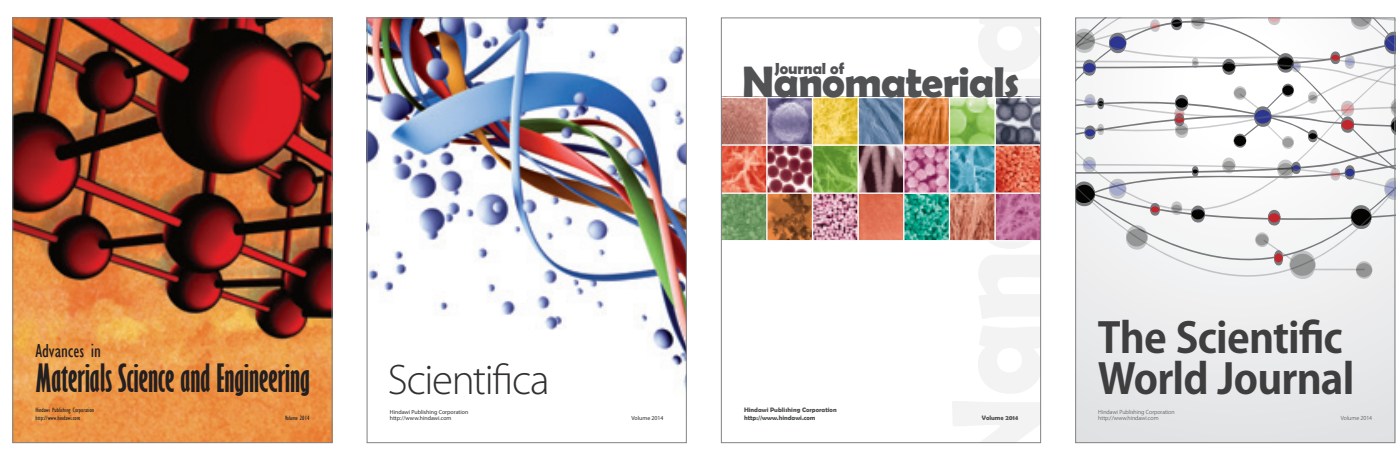

\section{The Scientific World Journal}
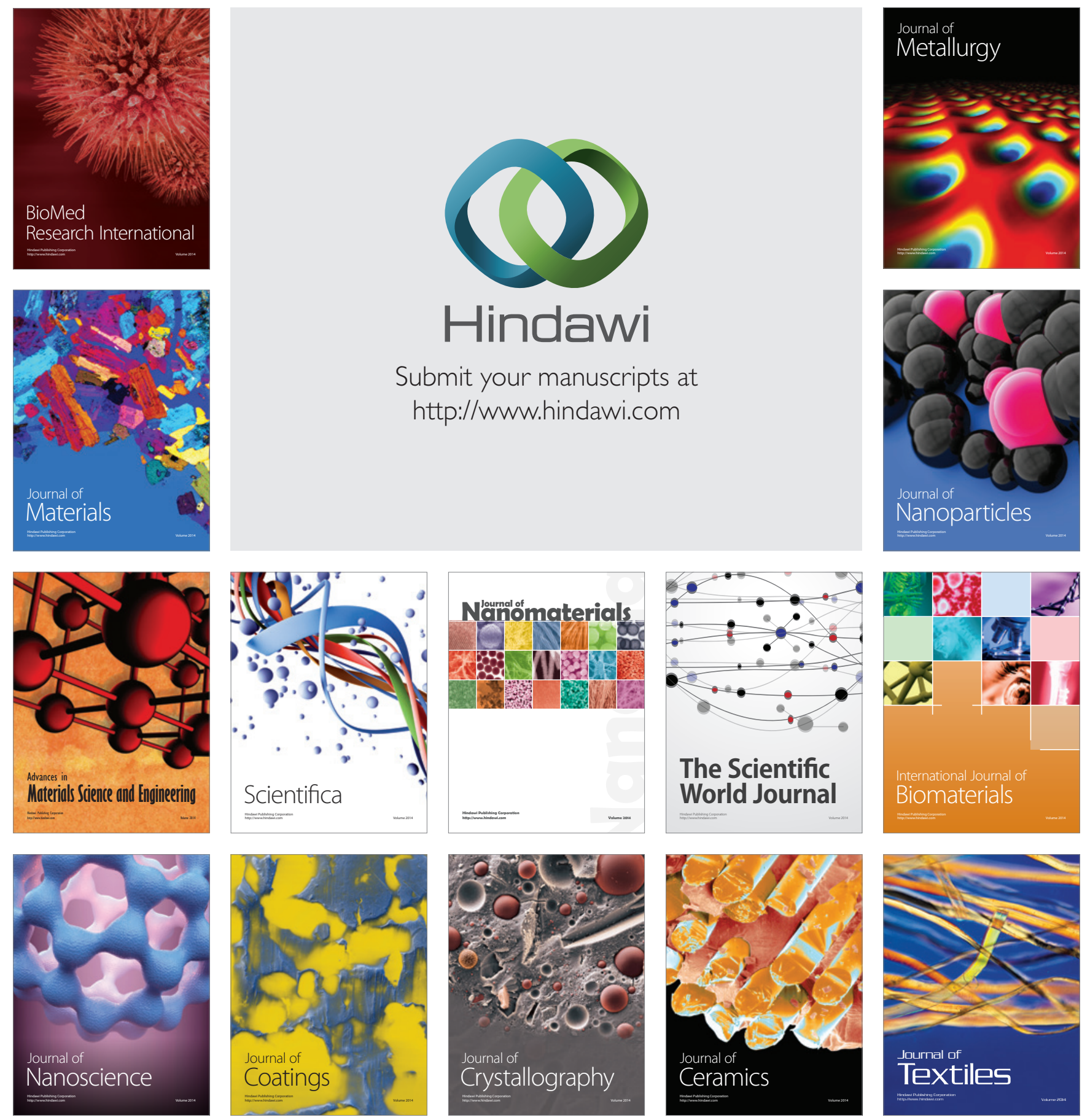